\title{
Galls Induced by Diplolepis spinosa Influence Distribution of Mineral Nutrients in the Shrub Rose
}

\author{
G. Bagatto, T.J. Zmijowskyj, and J.D. Shorthouse' \\ Department of Biology, Laurentian University, Sudbury, Ont. \\ P3E 2C6, Canada
}

\section{Additional index words. Hymenoptera, Cynipidae, Rosa rugosa, plant stress}

\begin{abstract}
Mineral nutrient levels in tissues of the domestic shrub rose (Rosa rugosa Thunb.) were examined following gall induction by the cynipid wasp Diplolepis spinosa (Ashmead). Higher levels of $\mathrm{Cu}, \mathrm{Zn}, \mathrm{Fe}, \mathrm{Mn}$, and $\mathrm{Ni}$ were found in the galls, leaves protuding from the galls, and stems to which galls are attached than were found in normal stems and leaves, indicating that cynipid galls alter the nutritional status of their hosts. Cynipid galls must be removed or controlled because the stress they cause will increase the vulnerability of roses to attack by other pestiferous insects.
\end{abstract}

Two species of gall-inducing cynipid wasps [Diplolepis spinosa and Diplolepis radicum (Osten Sacken)], normally found only on the wild rose (Rosa blanda Ait.), are now attacking the domestic shrub rose in Canada and the northern United States (Shorthouse, 1988). Although galls of both species alter the aesthetic appearance of shrub roses, there have been no attempts to determine whether or not these insects cause structural or physiological damage. Most gall-inducing insects are thought not to cause host damage; however, there are studies showing that galls are physiological sinks for assimilates and macronutrients (Abrahamson and Weis, 1987). Here we report on how one of these insects, the stem-galler Diplolepis spinosa, alters the nutritional status of attacked stems.

Diplolepis spinosa is a small, rufous-orange cynipid wasp, the larvae of which induce a large, spiny, multi-chambered stem gall (Fig. 1). Like all gall insects, D. spinosa receives food and shelter from the host plant as the larvae stimulate and then control wound or defensive reactions of attacked organs. The gall undergoes three phases of development referred to as initiation, growth, and maturation (Rohfritsch and Shorthouse, 1982). In most cases, the gall prevents further stem growth; however, stunted, chlorotic leaves are commonly associated with the gall opposite the point of attachment (Fig. 1). On four occasions we found flower buds associated with maturing galls, and in all cases the buds were stunted and failed to open.

In Aug. 1989 we collected four normal unbranched sucker shoot stems of Rosa rugosa and four sucker shoot stems with typ-

Received for publication 28 Dec. 1990. This research was supported by grants from the Natural Sciences and Engineering Research Council of Canada, the Laurentian Univ. Research Fund, and the American Rose Society. The cost of publishing this paper was defrayed in part by the payment of page charges. Under postal regulations, this paper therefore must be hereby marked advertisement solely to indicate this fact.

'To whom reprint requests should be addressed. ical galls in the maturation phase. Each of the stems was $\approx: 30 \mathrm{~cm}$ long and was removed from an urban roadside flower bed in Sudbury, Ont. The normal stems were separated into leaves and the top $5 \mathrm{~cm}$ of the stem. The galled stems were separated into a 5-cm sample of stem below the gall, leaf tissues associated with the gall, and tissues of the gall itself. Stem and leaf samples for each category of tissue were pooled, ovendried, homogenized in a plant mill, and digested in boiling aqua regia, and elemental analysis was performed by flame atomic absorption spectrophotometry. Gall tissues were not pooled, and each was analyzed separately. Details of the analytical technique are described by Bagatto and Shorthouse (1991).

Values for $\mathrm{Ca}, \mathrm{Mg}$, and $\mathrm{Mn}$ in the leaves and stems of the control samples (Table 1) are considerably lower than those reported in the literature (Carlson and Bergman, 1966; Diaz et al., 1985; Johansson, 1978); however, the study plants appeared healthy and were producing numerous blossoms. Values for the remaining nutrients in the nongalled stems fall within the range considered ade- quate for roses. However, all nutrients, except $\mathrm{Ca}$ and $\mathrm{Mg}$, were present in far higher concentrations in the gall and in the associated leaf and stem tissues than they were in the nongalled stems. Extremely high concentrations of $\mathrm{Cu}, \mathrm{Zn}, \mathrm{Fe}$, and $\mathrm{Ni}$ were found in the stunted leaves proximal to the galls (Table 1). Levels of mineral nutrients in the gall leaves were higher than levels in the galls themselves. The leaf concentrations for Mn were similar for normal leaves and gall leaves.

The higher levels of some nutrients in leaves associated with the galls than the galls are difficult to explain. We suspect that galls of $D$. spinosa and the larvae within direct movement of nutrients from the host plant through the xylem of the gall and eventually into the leaves; however, remobilization from the gall leaves may be prevented because of modified phloem flow. Furthermore, gall leaves become chlorotic and necrotic, thus, an accumulation of mineral nutrients and interrupted vascular flow may account for this appearance: Histological studies of stem, gall, and associated leaf tissues could examine this possibility.

The preliminary findings reported here illustrate that galls of $D$. spinosa alter the mineral nutritional status of their host plants. They provide further evidence that galls are

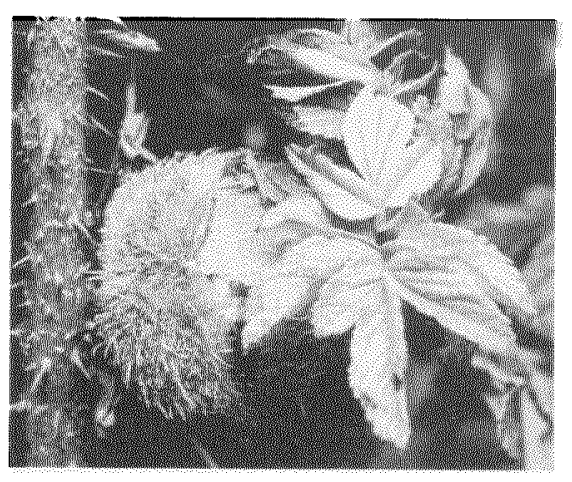

Fig. 1. Mature gall on stem of Rosa rugosa. Note stunted leaves associated with the gall.

Table 1. Nutrient content for various tissues of Rosa rugosa. Plants collected in Aug. 1989 during the maturation phase of gall development.

\begin{tabular}{|c|c|c|c|c|c|}
\hline \multirow[b]{2}{*}{ Nutrient $^{2}$} & \multicolumn{2}{|c|}{ Leaf } & \multicolumn{2}{|c|}{ Stem } & \multirow[b]{2}{*}{ Gall ${ }^{x}$} \\
\hline & Normaly & Gall & Normaly & Gall & \\
\hline$\overline{C a}$ & $\begin{array}{c}31.0 \\
(70-190)\end{array}$ & 15.0 & $\begin{array}{c}28.0 \\
(40-70)\end{array}$ & 50.0 & $11.0 \pm 2.9$ \\
\hline $\mathrm{Mg}$ & $\begin{array}{c}16.0 \\
(30-40)\end{array}$ & 15.0 & $\begin{array}{c}7.0 \\
(16-26)\end{array}$ & 5.0 & $10.0 \pm 1.4$ \\
\hline $\mathrm{Cu}$ & $\begin{array}{c}11.8 \\
(8-15)\end{array}$ & 209.0 & $\begin{array}{c}11.2 \\
(6-20)\end{array}$ & 23.9 & $60.3 \pm 9.1$ \\
\hline $\mathrm{Zn}$ & $\begin{array}{c}19.6 \\
(25-30)\end{array}$ & 51.3 & $\begin{array}{c}15.6 \\
(25-40)\end{array}$ & 59.8 & $16.4 \pm 2.6$ \\
\hline $\mathrm{Fe}$ & $\begin{array}{c}49.6 \\
(38-94)\end{array}$ & 895.0 & $\begin{array}{c}11.7 \\
(18-80)\end{array}$ & 84.2 & $128.0 \pm 42.2$ \\
\hline Mn & $\begin{array}{c}29.7 \\
(260-988)\end{array}$ & 31.5 & $\begin{array}{c}18.9 \\
(70-232)\end{array}$ & 35.6 & $25.5 \pm 9.6$ \\
\hline $\mathrm{Ni}$ & 14.4 & 110.0 & 9.5 & 22.6 & $38.4 \pm$ \\
\hline
\end{tabular}

${ }^{z}$ Values for $\mathrm{Ca}$ and $\mathrm{Mg}$ are given as parts per 10,000 dry weight, remaining nutrients as $\mu \mathrm{g} \cdot \mathrm{g}^{-1} \mathrm{dry}$ weight.

${ }^{y}$ Reported tissue concentrations in nutritionally sufficient rose plants given in parentheses (Carlson and Bergman, 1966; Diaz et al., 1985; Johansson, 1978).

${ }^{\times}$Means shown $\pm \mathrm{SE}$. 
physiological sinks and support the contention that galls, and the insects within, drain nutrients from their host plants (Abrahamson and Weis, 1987; Andersen and Mizell, 1987). Furthermore, the high concentrations of several nutrients in the galls and adjoining stem tissues suggest that $D$. spinosa mobilizes nutrients from other parts of the host plant. However, for the rose grower, the results provide evidence that cynipid galls stress their hosts and should be controlled or removed. This precaution could be of particular importance when roses are growing in nutrientdeficient soils.

Future studies of this gall system and others should include an examination of growth rates of galled and nongalled stems, along with a study of how galls alter the architecture of their host plants. The results presented here indicate that galled plants are stressed, and since stressed plants are commonly more vulnerable to insect attack than healthy plants (Cockfield, 1988), the possibility exists that galled roses will be more susceptible to attack by other phytophagous pests.

\section{Literature Cited}

Abrahamson, W.G. and A.E. Weis. 1987. The nutritional ecology of arthropod gall-makers, $\mathrm{p}$. 235-238. In: F. Slansky and J.G. Rodriguez (eds.). The nutritional ecology of insects, mites and spiders. Wiley, New York.

Andersen, P.C. and R.F. Mizell, III. 1987. Physiological effects of galls induced by Phylloxera notabilis (Homoptera: Phylloxeridae) on pecan foliage. Environ. Entomol. 16:264-268.

Bagatto, G. and J.D. Shorthouse. 1991. Accumulation of copper and nickel in plant tissues and galls of Hemadas nubilipennis (Hymenoptera: Pteromalidae) on lowbush blueberry near an ore smelter at Sudbury, Ontario, Canada. Can. J. Bot. (In press.)

Carlson, W.H. and E.L. Bergman. 1966. Tissue analysis of greenhouse roses (Rosa hybrida) and correlation with flower yield. Proc. Amer. Soc. Hort. Sci. 88:671-677.

Cockfield, S.D. 1988. Relative availability of nitrogen in host plants of invertebrate herbivores: Three possible nutritional and physiological definitions. Oecologia 77:91-94.

Diaz, A., M. Fernandez-Falcon, V. Garcia, and L Sosa. 1985. Study of nutrient distribution in the rose bush for foliar diagnostic purposes. Agrochimica 29(5-6):428-434.

Johansson, J. 1978. Effects of nutrient levels on growth, flowering and leaf nutrient content of greenhouse roses. Acta Agr. Scandinavia. 28:363-386.

Rohfritsch, O. and J.D. Shorthouse. 1982. Insect galls. p. 131-152. In: G. Kahl and J.S. Schell (eds.). Molecular biology of plant tumours. Academic, New York.

Shorthouse, J.D. 1988. Occurrence of two gall wasps of the genus Diplolepis (Hymenoptera: Cynipidae) on the domestic shrub rose, Rosa rugosa Thunb. (Rosaceae). Can. Entomol. 120:727-737. 